\title{
O.I. Fediv, I.O. Sitsinska \\ DYSLIPIDEMIA AND RHEOLOGICAL CHANGES IN THE BLOOD OF PATIENTS WITH PEPTIC ULCER OF STOMACH AND DUODENUM, COMBINED WITH HYPERTENSION AND DIABETES MELLITUS TYPE 2
}

Higher State Educational Institution “Bukovinian State Medical University” (Chernivtsi)

Abstract. The article shows the changes in lipid metabolism and rheological properties of red blood cells in patients with peptic ulcer of stomach and duodenal ulcers, combined with hypertension and diabetes mellitus type 2 .

Development and relapse of peptic ulcer of stomach (PUS) and duodenum (PUD) in more than $90 \%$ are associated with infection H.pylori (Hp). However, the prevalence of hypertension $(\mathrm{AH})$ and diabetes mellitus type 2 (DM2) in combination with PUD complicate not only the diagnosis, but their course $[2,3,4]$.

In recent years, the prevalence of these pathologies combination has increased by almost $10 \%[1$, $3]$. There are fundamental changes in terms of the state of homeostasis and vascular-endothelial dysfunction in PUD and PUS, combined with hypertension and diabetes mellitus type 2 .

Objective: to evaluate the lipid metabolism and blood rheology in patients with peptic ulcer of stomach and duodenal ulcers, combined with hypertension and diabetes mellitus type 2 .

Material and methods. 65 patients were involved in the clinical examinations. Of these 15 persons were practically healthy (Group №1), 25 persons ill with PUD and PUS (Group № 2), 25 persons - PUD and PUS, combined with hypertension and diabetes mellitus type 2 (Group №3).

27 of them $(54 \%)$ patients were males and 23 (46\%) - females, aged 19 to 64 years old. The groups were compared by their sex and concomitant pathology.

Diagnoses were verified on the basis of history, general clinical and laboratory tests.

Blood for biochemical studies in patients was taken out of the cubital vein on an empty stomach in the morning, after a 12-15 hour fast. As a stabilizer we used heparin blood - to study the processes of peroxide in the blood; 3,8\% solution of sodium citrate studying the rheological properties of red blood cells.

The content of malonic aldehyde in the blood was determined by Y.A. Vladimirov and A.I. Archakov titration method.

The rheological properties of red blood cells were determined using filtration methods: erythrocytes deformity index (EDI) - Tannert C.method, Lux V. [1] in the modification of Z.D.Fedorova and M.O.Kotovshchykova ones [2], the relative viscosity of erythrocyte suspension (RVES) by O.F. Pyrohova, V.D. Dzhordzhykiya in modification with Z.D. Fedorova and M.O. Kotovshchykova methods.

Lipid metabolism was determined by means of an automated biochemical selective analyzer
Key words: gastric ulcer, hypertension, diabetes, lipoproteins, atherogenic factor, blood rheology.

«KONELAB 20th." Biochemical studies included determining lipid concentrations of total cholesterol (TC), triglycerides (TG), low density lipoprotein cholesterol (LDL), high density lipoproteins (HDL). Atherogenic cholesterol ratio (SV) was calculated by A.M Klimov formula.

$$
\mathrm{KA}=(\mathrm{SW}-\mathrm{C}) / \mathrm{HDL}
$$

Statistical analysis was performed using materials package Statistics 17,0.

Results and Discussion. As a result of the study TC is $(4,58 \pm 0,23)$ in group № 2 , in group №3 $(5,32 \pm 0,07)$ and group №1 $(4,17 \pm 0,29) \quad(\mathrm{p}<0,05)$, indicating an increase by $1,15 \%$ compared with group №3.

However, there are some TG changes being in

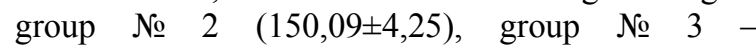
$(221,21 \pm 9,47)$, and group № $1-(133,62 \pm 4,39)$ $(\mathrm{p}<0,05)$. It was established that this figure rose by 1.65 times in group 3 compared with the group of healthy individuals.

HDL in the second group was $(0,96 \pm 0,07)$, and in the third - $(0,86 \pm 0,06)$, which tends to decrease in the third group. Compared with the control group $(1,33 \pm 0,13)$, reducing performance group №1 and №2. As a result of investigations proved significant decrease in HDL by 1,54 times in №3 group compared with group № 1 .

When identifying LDL we found that LDL in group 2 was $(2,9 \pm 0,21)(\mathrm{p}<0,05)$ in group № 3 $(3,43 \pm 0,10)(\mathrm{p}<0,05)$, indicating the rate increase by $0,56 \%$ compared with group № $1(2,87 \pm 0,42)$ $(\mathrm{p}<0,05)$. It was proved uncontrolled increase in total cholesterol $22 \%$, triglyceride levels - $11 \%$ atherogenic factor - $48 \%$ low density lipoprotein - by $16 \%$ and decrease HDL by $35 \%$.

Hyperinsulinemia promotes atherogenic dyslipidemia, enhances the proliferation of smooth muscle cells and fibroblasts, increases the activity of LDL receptors and endogenous cholesterol synthesis in cells of the vascular wall.

It was proved that the $\mathrm{AC}$ is in the second group is $(4,21 \pm 0,43) \quad(p<0,01)$, the third $(5,2 \pm 0,37)$ $(\mathrm{p}<0,01)$, which is increased by $2,52 \%$ compared with the first group $(2,68 \pm 0,53)$.

It is known that MA as one of the end products of lipid peroxidation, shows a toxic effect, forming "crosslinks" of biopolymers, and in patients with increased MA content may be one of the causes of

(C) O.I. Fediv, I.O. Sitsinska, 2015 
degradation of structural elements of the mucous membrane of the stomach and duodenum.

We showed the changes of MA in blood plasma (MA pl). We found out that MA pl. in the second group was $(3,56 \pm 0,17)$, in the third $-(3,69 \pm 0,15)$ and the first - $(2,45 \pm 0,23)$, which by $1,11 \%$ and $1,18 \%$ more than in the group of healthy individuals.

Meanwhile, the MA in erythrocytes (MA er.) in a group №2 is $(10,23 \pm 0,47)$, group № 3 $(10,34 \pm 0,42)$, group № $1-(6,89 \pm 0,37)$. There was an increase of MA er. in group №3 by 1,5 times compared with the group № 1 .

While studying EDI and RVES we established that indices of EDI in group № $2(47,95 \pm 1,66)$ and group № $3(43,48 \pm 1,38)$ reduced, compared with the group of healthy individuals. However, RVES in groups № $2(1,45 \pm 0,91)$ and № $3(2,06 \pm 0,66)$ increased with group № $1(1,34 \pm 0,17)$, which explains their relationship.

It was proved that the presence of metabolic syndrome, recurrent peptic ulcer and duodenal ulcer is more significant than in the absence of accompanying diseases, disorders of structural and functional properties of erythrocytes (red blood cells increasing the relative viscosity by $34 \%$ and a decrease of red blood cells deformity index $44 \%$ ), increase of lipid peroxidation (malonic aldehyde in erythrocytes by $43 \%$ and malonic aldehyde in plasma by $44 \%$ ).

\section{Conclusions}

1. Patients with peptic ulcer of the stomach and duodenum, combined with hypertension and diabetes mellitus type 2 had changes in lipid metabolism, rheological properties of erythrocytes and lipid peroxidation according to sex and age of patients.

2. The essential pathogenetic factor of recurrence and complications of patients with peptic ulcer of the stomach and duodenum, combined with hypertension and type 2 diabetes have uncontrolled increase in total cholesterol $22 \%$, triglyceride levels $11 \%$ atherogenic factor $-48 \%$ low density lipoprotein - by $16 \%$ and decrease HDL by $35 \%$.

3 . In the presence of metabolic syndrome, recurrent peptic ulcer and duodenal ulcer is more significant than in the absence of accompanying diseases, disorders of structural and functional properties of erythrocytes (red blood cells increasing the relative viscosity by $34 \%$ and a decrease of red blood cells deformity index $44 \%$ ), increase of lipid peroxidation (malonic aldehyde in erythrocytes by $43 \%$ and malonic aldehyde in plasma by $44 \%$ ).

4. Long-term complex maintenance therapy with observing age of the patient, the peculiarities of changes of lipid peroxidation, structural and functional properties of red blood cells, changes in lipid profile is an effective treatment method for peptic ulcer disease and duodenal ulcer in the presence of comorbidity.

\section{References}

1. Association between vascular endothelial growth factor and hypertension in children and adolescents type I diabetes mellitus / K. Zorena1, J. Mys'liwska, M. Mys'liwiec // J. Hum. Hypert. - 2010. - Vol. 24. - P. 755 -762.

2. Bener A. Association between type 2 diabetes mellitus and mellitus infection / A. Bener, R. Micallef, M. Afifi // J.Gastroenterol. - 2007. - Vol. 18, № 4. - P. 225-229.

3. Boehme M. Prevalence of silent gastric ucler, erosions of Severe acute gastritis in patients with type 2 diabetes mellitus: A cross sectional study / M. Boehme, F. Autschbach, C. Ell // Hepatogastroenterol. J. - 2007. Vol. 54, № 74. - P. 643-648.

4. Kumar P. Effect of L-arginine on electrocardiographic changes induced by hypercholesterolemia and isoproterenol in rabbits / P. Kumar, M. Goyal, J.L. Agarwal // Ind. Pacing Electrophysiol. J. - 2009. - № 9(1). - P. 45-52.

\section{ДИСЛИПИДЕМИЯ И РЕОЛОГИЧЕСКИЕ ИЗМЕНЕНИЯ В КРОВИ У БОЛЬНЫХ С ПЕПТИЧЕСКОЙ ЯЗВОЙ ЖЕЛУДКА И ДВАНАДЦЯТИПЕРСТНОЙ КИШКИ, СОЧЕТАННОЙ С АРТЕРИАЛЬНОЙ ГИПЕРТЕНЗИЕЙ И САХАРНЫМ ДИАБЕТОМ ТИПА 2}

\section{А.И. Федив, И.А. Сицинская}

Резюме. В статье приведены данные изменений липидного обмена и реологических свойств эритроцитов у больных пептической язвой желудка и двенадцатиперстной кишки, сочетанной с артериальной гипертензией и сахарным диабетом типа 2.

Ключевые слова: язва желудка, артериальная гипертензия, сахарный диабет типа 2, липидный обмен, реологические свойства крови.

\section{ДИСЛІПІДЕМІЯ ТА РЕОЛОГІЧНІ ЗМІНИ В КРОВІ У ХВОРИХ НА ПЕПТИЧНУ ВИРАЗКУ ШЛУНКА ТА ДВАНАДЦЯТИПАЛОЇ КИШКИ, ПОЄДНАНОЇ 3 АРТЕРІАЛЬНОЮ ГІПЕРТЕНЗІСЮ ТА ЦУКРОВИМ ДІАБЕТОМ ТИПУ 2}

\section{О.I. Федів, I.O. Сіцінська}

Резюме. У статті наведено дані змін ліпідного обміну та реологічних властивостей еритроцитів у хворих на пептичну виразку шлунка та дванадцятипалої кишки, поєднаної з артеріальною гіпертензією та цукровим діабетом типу 2.

Ключові слова: виразка шлунка, артеріальна гіпертензія, цукровий діабет типу 2, ліпідний обмін, реологічні властивості крові.

Вищий державний навчальний заклад України «Буковинський державний медичний університет», м. Чернівці

Рецензент - проф. О.І. Волошин

Buk. Med. Herald. - 2015. - Vol. 19, № 3 (75). - P. 192-193 